\title{
Batik Education and Competency Certification in Indonesia
}

\author{
Rodia Syamwil ${ }^{1}$, Amalia $^{2}$, Atika $^{3}$, Sicilia Sawitri $^{4}$ \\ rodiasyamwil@mail.unnes.ac.id ${ }^{1}$, amalia@dsn.dinus.ac.id ${ }^{2}$, atikaft@mail.unnes.ac.id ${ }^{3}$ \\ Universitas Negeri Semarang ${ }^{1,3,4}$ \\ Universitas Dian Nuswantoro ${ }^{2}$ \\ Asessor of LSP Batik ${ }^{1,2,3}$
}

\begin{abstract}
Along with one decade of the inauguration of batik as the world intangible cultural heritage of humanity, various conservation efforts have being done, including education. Batik education and training programs are growing rapidly through formal, informal and non-formal education. For tourism, people introduce batik to foreigner in their workshop. Batik also becomes an excellent program in 30 of Textile Craft Vocational Secondary Schools spread throughout Indonesia including Papua, to create human resources in batik industries. Besides, batik workshops are also organized in non0formal education. At least there are about 33 Balai Latihan Kerja (BLK) the Competency Based Training under government and private organized batik program. Ministry of Industry as the leading sector of batik industry, also develop education and training program through Industrial Training Agency (BDI). To assure the professional competency of batik worker and worker candidate, certification is conducted by Professional Certification Authority or Lembaga Sertifikasi Profesi (LSP) Batik. This paper will analyzed all aspect about batik education and certification program in Indonesia.
\end{abstract}

Keywords: Batik, Education, Competency, Certification

\section{Introduction}

In 2009, when UNESCO recognized batik as the intangible cultural heritage of humanity origin from Indonesian, the batik industry resumed its rise from lost generation to a business with bright prospects. Batik industries in Indonesia, especially in Java was ups and downs along the centuries. Reached the golden age of the 9th to 20th centuries, and rapid development in 1970 till 1997, the industry suffered a setback caused by monetary crisis, followed by various natural disasters and riots in Indonesia. However, batik industry could survived the crisis compared to other industries, though some were collapse, some reduced their production, and some diverted their products. For example, In Yogyakarta as much as 1200 unit batik industries in the early 1970s, remaining to be only 400 industries survived. The same thing happened in various regions, up to 70 percent of the craftsmen members were no longer active as batik producers.

Start from 2007 batik industry rose from its downturn and adversity. Data from The Ministry of Industry said that batik sector is dominated by small and medium industries (IKM), has spread to 101 centers in Indonesia, with a total of around 47.755 batik industries in micro, small and medium scale exist in Indonesia spread in many areas, with $14 \%$ growth rate in 2019. Batik industry is a labor-intensive industry that is able to absorb up to 212,000 people, with a growth 
rate of $18.98 \%$. This figure can be compared with data from Indonesian Batik Craftsmen and Entrepreneurs Association or Asosiasi Pengrajin dan Pengusaha Batik Indonesia (APPBI) which noted that craftsmen who are members of APPBI are 151,565 people, while the number of batik industry 4393 industries consists of 502 (11\%) large industries, 1279 (29\%) medium industries and 2612 small industries (60\%). Meanwhile, there are still around $10 \%$ of micro and small industry becomes members of the association (APBBI, 2020).

The batik industry gets development priority because it is considered to have a great leverage in the creation of added value and trade. Economically, batik products give the second largest contribution of $20-30 \%$ of gross domestic product (GDP) in the creative economy subsector. Evidently, the batik products produced have enormous opportunities for world trading, as a part of fashion. Batik leading in Indonesia product exports and contributors to foreign exchange through exports. Director General of Small, Medium and Various Industries of the Indonesia Ministry of Industry noted that exports from the batik industry during the first semester of 2019 reached US\$ 17.99 million or around 253 billion Rupiahs. Over the past year, batik exports reached US\$ 52.4 million or around 747 billion Rupiahs. Batik exports have penetrated a number of major destination countries such as Japan, the United States, and Europe. Besides, batik industry is part of the textile and clothing industry, which is one of the main sectors in the implementation of the Making Indonesia 4.0 road map. Batik industry received development priority because it was considered to have a large leverage in creating added value, trade, the amount of investment, the impact on other industries, and the speed of market penetration. With the world trade value of apparel products reaching a total of US \$ 442 billion, the Indonesian batik industry has the opportunity to increase market share. In addition, the development of industry 4.0 and various advanced technologies and digitalization are expected to make the national batik world more competitive. Indonesian batik is also believed to have comparative and competitive advantages in international market competition.

Batik industry is a tough industries, it could pass any difficult situation. In the Covid-19 pandemic, Darmawan (2020) reported that sales of handwritten batik and stamped batik have decreased dramatically, where the loss reached 25 billion rupiah. However, creatively the batik businessman and entrepreneurs shifted the sales system from direct sales towards social mediabased online sales. Batik production is partly diverted to the production of protective equipment such as masks, and the production of house clothing that can be used for work at home. Sales of house clothing increased.

Batik education becomes critical in relation to the development of industry 4.0 , because education is a means for preparing human resources. As the cultural heritage, batik transferred from one generation to the next generation through oral tradition or in-formal education. Though this type of education were lasted for centuries, but proved was less successful in creating the new generation. After monetary crisis in 1997 there are lost generation in batik, since many of young people chose other profession which they consider more prestigious. One year after UNESCO recognition, batik began to be taught in schools, and included in the formal education curriculum starting from primary, secondary, to higher education. Syamwil (2010) states that according to the level of age development, there are differences in the material taught at each level. At the elementary school level, batik education is only at the awareness stage, at the junior secondary level, it is at the orientation and operation stage, at the high school / vocational level, batik education is at the vocational or occupational stage. The entry of batik into the education curriculum, is an effort to safeguard the sustainability of batik in Indonesia, and also aims at creating a competent workforce in the field of batik expertise. 
The purpose of this study is to figure the current condition of batik workers, who are selftaught, or train in any school or training program, as well as mapping the competency gap of these batik workers.

\section{Theoretical Background}

The definition of competency standards in Indonesia as the description of competencies embracing knowledge, skills, expertise and work attitudes that are relevant to tasks and requirements of regulatory authorithies [peraturan 2007 sayuti, 2015]. The policy of national competency standards (NCS) is discussed as an integral component of the broader policy of national qualification framework (NQF). The development of Indonesian Competency Standards was underpinned by foru regulations, i.e [Sayuti, 2015]: (a) Act Number 13 regarding manpower in 2003; (b) Ministerial Decree (KEPMEN) number 227 in 2003, 2004 and 2007; (c) Government regulation number 23 about Indonesian Professional Certification Authority (BNSP) in 2004; and (d) Government regulation (PP) Number 31 about national system for manpower training (SILATKERNAS) in 2006. The BNSP is the institution responsible for the development of the competency standards and for the certification of Indonesian Competency Standards.

\section{Research Method}

The objects of the research are the portrait of batik education in Indonesia, figured out kinds and level of education for batik, the position of competence workers as human resources, typical in gender and age, and the competency assurance for the workers. Data were collected through documents, observation, and open interview to the respondents consist of representative of Indonesian Batik Craftsmen and Bussines Association (APPBI), batik teachers and instructors, as well as some assessors from Batik Professional Certification Authority (LSP Batik). Data analyzed in qualitative approach.

\section{Research Findings}

\subsection{Condition of Batik Worker Today}

A decade ago, it was found that more than $85 \%$ of batik workers in some traditional batik centers were old people (over 60 years). However, in their old age, they are proven competent, such as in Bayat Klaten Central Java, there are number of woman aged over 80 years who are still competent in making handwritten batik. This condition foster worries about regeneration. From the gender aspect, $91.2 \%$ of handwritten batik were produced by female crafter, though it was also found some good male doing the job. Stamped batik crafter are generally male, but in Jambi, the stamping work was also done $90 \%$ by female crafter. Coloring batik with brush, known as coletan work are generally carried out by female, while dyeing are usually carried out by male and female respectively $50 \%$. Canting pen and canting stamp makers are generally male and $70 \%$ of the younger generation have entered this job market, but there is also one 
women who is competent in making canting stamp. The work of releasing batik wax is $100 \%$ done by male with varying ages. However in overall batik business is still dominantly controlled by female.

In the past, each batik maker must be able to work on batik from beginning to end. At that time, a batik crafter was able to make a motif, copy the motif onto the fabric, attach the batik wax to the cloth in accordance with the motif using canting, dye batik, and release the night. The creation of batik motifs is done through reflection and inner behavior. Although there is some work done together, but in principle every batik must be able to work on the entire batik process. At present, every step of batik process are done by different people. There are segmentation in the field of work, division of tasks, so that a piece of batik cloth is completed collaboratively. For example, there are some people who are competent in using canting for handwritten batik only, and know nothing about coloring or wax removing. A person could be very competent in designing batik motifs but do not competent at all in the work to make batik wax mixture. So there are specialization in task and duty.

In 2015, the only one and first authority for batik professional certification was formed, known as LSP Batik. The aim of is to give recognition and appreciation to professional batik workers in their field of work, refer to the Indonesian National Work Competency Standards (SKKNI Batik). Moreover, certification also aim to ensure the competence of 212,000 batik workers related to their competence. Information from LSP Batik shows that there are 14 certification schemes for professional referring to existing work specialization in batik sector, those are: (1) Batik Motif Drafter; (2) Batik Patern Maker; (3) Batik Motif Designer; (4) Handwritten Batik Crafter; (5) Stamped Batik Crafter; (6) Batik Wax Maker; (7) Synthetic Dyes Color Mixer; (8) Synthetic Color Dyer; (9) Natural Dyes Color Mixer; (10) Natural Color Dyer; (11) Wax Removing Worker; (12) Canting Maker; (13) Batik Stamp Maker; (14) Computer Based Batik Designer. Until 2019 LSP Batik has certified 71\% batik worker out of 11.000 person who were joint competency assessment. From $29 \%$ declared not yet competent, a competency gaps or lack of skills to produce product which standard operation.

\subsection{Batik Education and Training}

The results showed that people study batik for different reasons. Some people do it for awareness, some do for livelihood, however there are also do it just for hobbies and happiness. Batik education and training programs are growing rapidly through formal, informal and nonformal education. Batik industries introduce batik to their guest or foreigner in their workshop, just for awareness. However, generally industries train their batik workers by their own, to meet their standard. Batik also becomes an excellent program in more than 30 of Textile Craft Vocational Secondary Schools spread throughout Indonesia including Papua, to create human resources for industries. Government and private organization facilitate the Competency Based Training for free in Balai Latihan Kerja (BLK) in every province, city and district in the effort to create new entrepreneur and worker. Ministry of Industry as the leading sector of batik industry, also develop education and training program through Industrial Training Agency (BDI). Certification process showed that only $72 \%$ SMK graduate are competent, while it was only $46 \%$ competent, and fulfil the minimum requirement of National Batik Professional Competency Standard (SKKNI). The gaps happened, since many of training and education programs did not use SKKNI as a curriculum reference.

Along with the growth of the industry and the development of batik trade to the export level, more and more people want to learn about batik. At first batik was taught by oral tradition, word of mouth, but now batik has entered the school curriculum generally in the form of local 
content. Batik education is now a prima donna and something that attracts the interests of all walks of life. Tourism also offers batik tours to local and foreign tourists. Batik higher education programs have also been opened in several cities known as batik centers. For example, the Faculty of Batik which was opened at Pekalongan University, also in the form of polytechnics such as Pusmanu Polytechnic in Pekalongan. Some quality universities also open batik programs, such as Binus International, Semarang State University and other educational universities that have a Fashion Study program.

Batik education and training programs are growing rapidly through formal, informal and non-formal education. For tourism, people introduce batik to foreigner in their workshop. Batik also becomes an excellent program in 30 of Textile Craft Vocational Secondary Schools spread throughout Indonesia including Papua, to create human resources in batik industries. Besides, batik workshops are also organized in non-formal education. At least there are about 33 Balai Latihan Kerja (BLK) the Competency Based Training under government and private organized batik program. Ministry of Industry as the leading sector of batik industry, also develop education and training program through Industrial Training Agency (BDI).

Batik education development cannot be separated from vocational education concept i.e.: education for all, education for life, education for earning a living, inclusive education.

1) "Batik Education for All" is one of the conservation efforts so that knowledge about batik is spread to various levels of society, various levels of education. In addition, batik knowledge must also be spread throughout the world. It can be said that batik education is intended to increase awareness of batik. This education for all comes in the form of local and extra-curricular curriculum in schools at elementary and junior high school levels. Or in the form of one day workshops or short-courses that are held in industry, at education centers, or at batik exhibitions. Simple knowledge and skills are taught here in a practical and fun way.

2) Batik Education for Hobby and Leisure, where batik program usually attended by retired people, or housewives to fill their leisure time and gain happiness for that.

3) Batik Education for Therapy, where the process of making batik is considered as fun and relaxing activity. Therefore doctors recommend to cancer survivors or those who are stressed to learn batik. The results have been proven, that some cancer survivors in Jakarta got their spirits up when given the opportunity to make batik in an easy way. They produce batik paintings on display at a batik festival.

4) Batik Education for Earning a Living, is the concept of vocational education or occupational education in the level of development, advancement and establishment. Syamwil and Soenarto (2010) state that batik education is included in the formal education curriculum as both local and extra-curricular content. in there are various vocational levels according to age and education level. At the kindergarten and elementary level, they are in the awareness stage, in junior high at the Orientation and Exploration level, SMK at the Development level, at the Higher Education Advanced stage, and while working at the Establishment Stage. This education is carried out for batik workers, according to their profession. Batik has becomes an excellent program in 30 of Textile Craft Vocational Secondary Schools spread throughout Indonesia including Papua, to create human resources in batik industries. Besides, batik workshops are also organized in non-formal education. At least there are about 133 Work Training Centers (BLK) of the Competency Based Training under the government and private organized batik program. Ministry of Industry as the leading sector of the batik industry, also develops education and training programs through the Industrial Training Agency (BDI). At the end of education and training, competency assessment and certification were conducted by LSP P1, P2, or P3. 
5) Batik Education for Disability. This kind of batik training is inclusion in nature, where batik work can also be done by people with disabilities, to provide an opportunity for them to be able to live independently not dependent on others. Ani Ulfatus and Rodia Syamwil (2014) stated that people with disabilities can be trained in batik making with the assistance of experts. LSP Batik can also certify competencies for them with the help of experts.

\section{Conclusion}

There is a change in batik education which was initially informal in the family to formal and non-formal education. In forming and supporting the development of robust batik industry, they requires professional and competent human resources or workers. Therefore, all formal and non-formal education must refers to the SKKNI in developing a competency-based curriculum. Certification was carried out by an independent institution namely LSP in the P1, P2, and P3 categories under BNSP supervision. Not all batik workers are certified. Only $71 \%$ of the 11,000 of batik workers who performed the competency test was passed the test.

\section{References}

[1] Prasetyono, H., Kurniasari, D., \& Desnaranti, L.: Evaluation of the implementation of Batik-skills training program. Research and Evaluation in Education Vol. 5 no. 2, pp. 130-143 (2019)

[2] Kurniasari, D, Widodo, S. E. \& Sujanto, B.: Evaluation of skills for doing batik at batik cources. Indonesian Journal of Educational Review. Vol. 6 no. 1, pp. 11-21 (2019)

[3] Putri, A. S. \& Aznam, N.: The effect of the science web module integrated on Batik's local potential towards students' critical thinking and problem solving. Journal of science learning. Vol. 2 no. 3, pp. 92-96 (2019)

[4] Garavan, T. \& McGuire, D.: Competencies \& workplace learning: some reflection on the rhetoric $\&$ the reality. Journal of workplace learning. Vol. 13 no. 4, pp. 144-164 (2001)

[5] Vathanophas, V. \& Thai-ngam, J.: Competency requirements for effective job performance in The Thai Public Sector. Contemporary Management Research. Vol. 3 no. 1, pp. $45-70$ (2007)

[6] Sayuti, M.: The Indonesian competency standards in technical and vocational education and training: an evaluation of policy implementation in Yogyakarta Province Indonesia. Thesis of Doctor of Philosophy. The university of Newcastle, Australia (2015)

[7] Syamwil, R., \& Soenarto: Pengembangan Model Muatan Pra-vokasional dan pembelajaran dalam kurikulum SMP/MTs di sentra batik. Dissertation. Universitas Negeri Yogyakarta (2010). 